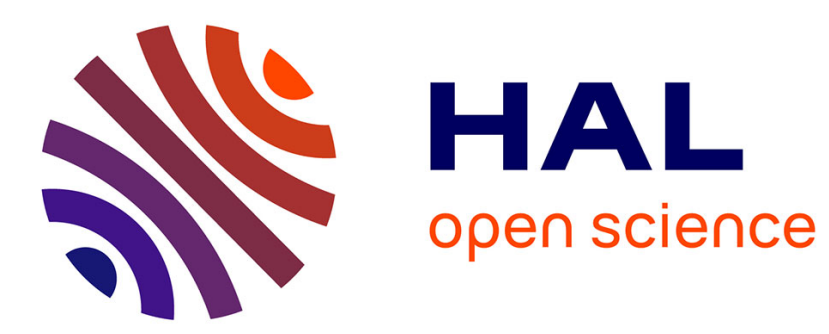

\title{
eMICAM a New Generation of Active DNA Chip with in Situ Electrochemical Detection
}

\author{
Raymond Campagnolo
}

\section{To cite this version:}

Raymond Campagnolo. eMICAM a New Generation of Active DNA Chip with in Situ Electrochemical

Detection. DATE'05, Mar 2005, Munich, Germany. pp.1338-1339. hal-00181312

\section{HAL Id: hal-00181312 \\ https://hal.science/hal-00181312}

Submitted on 23 Oct 2007

HAL is a multi-disciplinary open access archive for the deposit and dissemination of scientific research documents, whether they are published or not. The documents may come from teaching and research institutions in France or abroad, or from public or private research centers.
L'archive ouverte pluridisciplinaire HAL, est destinée au dépôt et à la diffusion de documents scientifiques de niveau recherche, publiés ou non, émanant des établissements d'enseignement et de recherche français ou étrangers, des laboratoires publics ou privés. 


\title{
eMICAM a New Generation of Active DNA Chip with in Situ Electrochemical Detection
}

\author{
Raymond Campagnolo, CEA/LETI-DTBS, Grenoble, France
}

\begin{abstract}
Most of the DNA chips available on the market are based on external or internal optical detection (fluorescence or chemiluminescence) and need a bulky chip reader (optics, laser, camera or PMT). We will present a new detection strategy using direct electrochemical detection of DNA hybridisation using conductive polymers grafted on an active silicon chip. We will report results on the first step of the fabrication process and emphasis on full wafer electropolymerisation of DNA probes on modified CMOS technology.
\end{abstract}

\section{Introduction}

Since their first development in the late $80 \mathrm{~s}$, DNA hybridisation chips have evolved into a powerful tool providing complex informative data from nucleic acid sequences. This technology has proven invaluable in many fields of research and diagnostics [2]

The reading of DNA chip is usually based on fluorescence labelling of hybridised target molecules (Fig. 1)

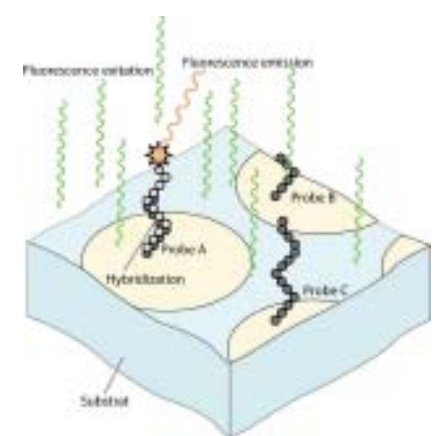

Fig. 1 : hybridisation and fluorescence detection

Combined with the use of confocal fluorescence scanners, this approach shows very high performance in terms of accuracy and sensitivity. But this requires a bulky instrument using lasers, optical filters CCD cameras or Photo Multiplier Tube and a high precision mechanical set-up.

However despite the feasibility of new generation readers with lower cost and reduced foot print [4], fluorescence readers remain costly and not transportable. This limits the use of DNA chips for both decentralised testing (point of care, air or water control, food testing,...) and as a routine tool in the field of diagnostics.
In order to reduce the size and cost of readers, other detection means have been proposed in which hybridisation of nucleic acids to the DNA chip can be directly related to an electrical signal. Electrochemical detection appears as the perfect candidate for this challenge. We will show how a method using electroactive polymers can be implemented at the wafer scale.

\section{Electrochemical detection using conductive polymer}

Miniaturized electrochemical detection systems rely on microfabricated electrodes monitoring redox reactions generated in the presence of hybridised targets or their labels. Applications have been reported for direct or indirect oxidation or reduction of nucleic acids, for electrochemically active reporter molecules or labels, and for redox reactions of molecules generated via enzymes labels $[5,6]$.

One challenge of these methods is the functionnalization step of the fabrication process needed for grafting the biomolecules on top or near the electrodes without modification of their properties.

The probe immobilization on the surface of the biochip is usually based on spotting of modified oligonucleotides or direct in situ synthesis of oligos by photochemistry. Both involved complicated surface chemistry using reagents that can impact conductive electrode surfaces. Spotting also suffers from a limited throughput because it's inherently a sequential process.

We have developed a technology [1], called MICAM ${ }^{\circledR}$, that overcomes these limitations. This technology is based upon electropolymerisation of conductive polymers on top of gold electrodes. A thin layer of a co-polymer (pyrrole and pyrrole-ODN) is produced so that oligonucleotides are grafted at a very precise locations (Fig. 2).

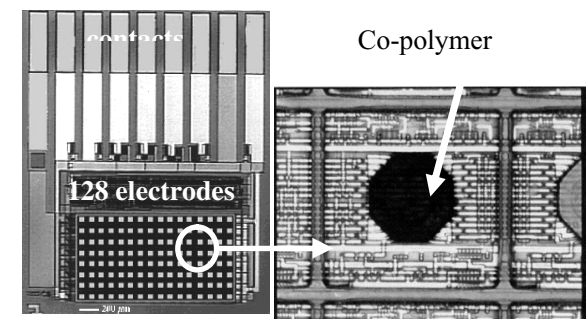

Fig. 2 : electropolymerisation of polymers bearing ODN 
The gold electrodes are multiplexed using an active silicon chip. The polymerisation step uses a very simple electrochemical procedure.

Once functionalised with oligonucleotides the polymer film can selectively recognize DNA targets. The specific hybridisation of the complementary target in solution induces a significant modification in the electrochemical response of polypyrrole and thus enables a direct electrical reading of the recognition process [3].

A very simple voltammogram (current measurement versus scan of potential) can be used to analyse the amount of hybridised complementary target (Fig. 3).

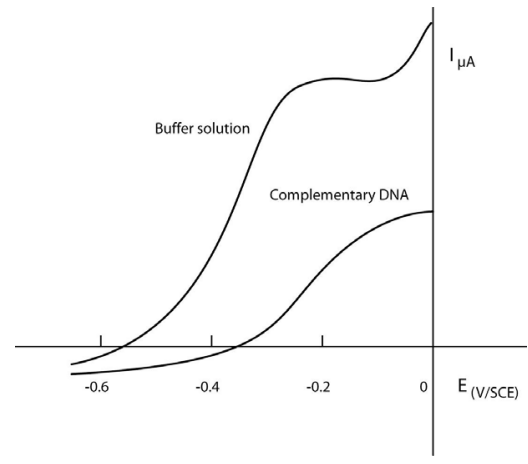

Fig. 3 : electrical reading of the hybridisation process

This method gives a direct access to high resolution analysis of DNA dots because no diffusion of electroactive mediator is involved (no cross-talk between electrodes).

\section{Wafer scale electropolymerisation on active CMOS chip}

Our main goal is to manufacture a low cost active biochip with high throughput thereby avoiding spotting. Based on our original MICAM ${ }^{\circledR}$ chip with 128 multiplexed electrodes, we performed a new design with intra-and inter-chip multiplexing enabling electrochemical grafting onto 500 chips in one step.

Specific post process for biocompatibility on CMOS standard technology and connection at the wafer level are two key issues of this approach (Fig. 4).

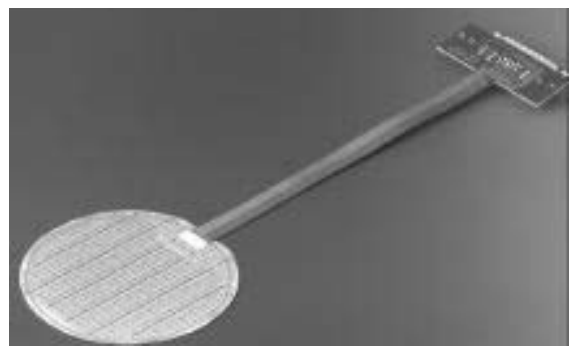

Fig. 4 : wafer connection before ODN grafting
The electrochemical cell is also adapted to reduce the reactive volume to be dispensed at each grafting step on the whole $100 \mathrm{~mm}$ wafer thus contributing to a drastic reduction of the cost (Fig. 5). This new kind of electrochemical deposition at an ultra thin thickness is promising for a wide range of applications, in particular in protein chip applications. By fluorescence imaging, we successfully measured a good grafting uniformity of 4$5 \%$.

After wafer fabrication, chips can be sawed, and picked and placed in a fluidic package.

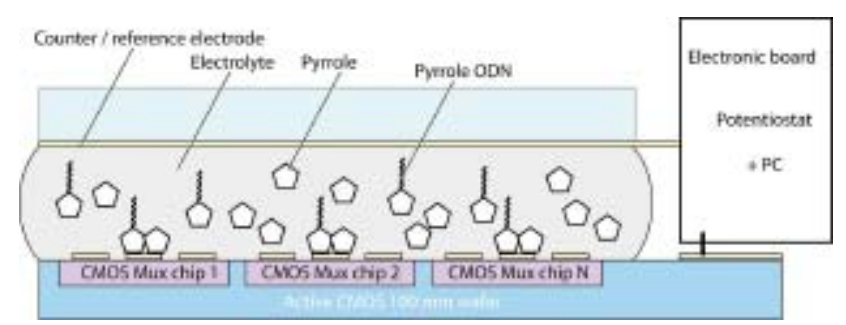

Fig. 5 : wafer parallel ODN grafting on electrodes

\section{Conclusion}

We have described here a new way to analyse DNA hybridisation combining conductive polymers used for grafting probes and for direct electrical reading of the recognition process. We have solved the first step of a high throughput fabrication process by using wafer scale electrochemistry. We are pursuing these developments by adding a current measurement circuit under each electrode.

\section{References}

[1] - Caillat P., Biochips on CMOS : an active matrix address array for DNA analysis, Sensors and Actuators B : Chemical, vol. 61, pp. 154-162,1999.

[2] - Epstein J.R, Biran I., Walt D.R., Fluorescence-based nucleic acid detection and microarrays, Anal. Chim. Acta 469, pp. 3-36, 2002

[3] - Kourri-Youssoufi H, Garnier F., Srivastava P., Toward biolectronics: specific DNA recognition based on an oligonucleotide functionalized polypyrolle, J. Am. Chem. Soc., Vol. 119, pp. 7388-7389, 1997

[4] - Perraut F., Lagrange A., Pouteau P., Peysonneaux O., Puget P., Mc Gall P., Menou L., Gonzalez R. Labeye P., Ginot F., A new generation of scanners for DNA chips, Biosens. Bioelectron. 17, pp. 803-813, 2002

[5] - Schienle M., Frey A., Hofmann F., Holzapfl B., Paulus C., Schindler-Bauer P., Thewes R., A fully Electronic DNA Sensor with 128 positions and In-Pixel A/D/ Conversion, Proc. ISSCC, pp 220, 2004

[6] - Wang J., Electrochemical nucleic acid biosensors. Anal. Chim. Acta 469, pp. 63-71, 2002 